\title{
What factors contribute to the self-reported oral health status of Arab adolescents? An assessment using a validated Arabic-WHO tool for child oral health (A-OHAT)
}

\author{
Ahmed M. Bokhari and Mir Faeq Ali Quadri* (D)
}

\begin{abstract}
Background: The current study was performed; to validate the Arabic version of WHO child oral health assessment tool (A-OHAT), to assess the oral health status of Arab school children and finally to identify the important risk factors associated with the poor teeth and gum conditions of school children.

Methods: A cross-sectional study with two-staged simple random sampling technique was implemented. A-OHAT, a self-assessment tool was subjected to psychometric analyses with the respondents being high school children. The Cronbach's alpha and the Intra class correlation values were computed. Paired t-test was performed to identify the differences between the readings after repeated administration, followed by the analysis for convergent validity. This tested Arabic-WHO Child-OHAT was administered to collect the data. Univariate, bivariate and logistic regression analyses were performed to report on the potential risk factors associated with poor teeth and poor gum conditions of school children.

Results: Psychometric analyses revealed that the Arabic Child Oral Health Assessment Tool (A-OHAT) was reliable and valid. A total of $478(\mathrm{~N})$ high school children were subjected to the tested tool, of which $66.5 \%$ were male and $33.5 \%$ were female with a mean age of $16.28+1.04$ years. $80.3 \%$ of school children had poor teeth condition and $36.2 \%$ of school children had often experienced toothache. Children had 1.5 times higher odds of having poor teeth condition if they had increased frequency of sweet and candy consumption. It was also seen that increased frequency of sweets and candy consumption by school children had put them at nearly $20 \%$ higher risk of having poor gum condition. Finally, children with the habit of using toothbrush had nearly $50 \%$ lower chance of having poor gum condition in contrast to the school children who do not use toothbrush.

Conclusion: To conclude, the study provides a reliable and valid tool to assess the oral health status of Arab adolescents. Improper oral hygiene habits and diet were identified as the plausible risk factors for poor teeth and gum condition.
\end{abstract}

Keywords: Validation, Oral health, Assessment tool, Arabic, Child, Oral diseases, Risk factors

\footnotetext{
* Correspondence: dr.faeq.quadri@gmail.com; fquadri@jazanu.edu.sa

Division of Dental Public Health, Department of Preventive Dental Sciences,

College of Dentistry, Jazan University, Gizan 45142, Saudi Arabia
}

(c) The Author(s). 2020 Open Access This article is distributed under the terms of the Creative Commons Attribution 4.0 International License (http://creativecommons.org/licenses/by/4.0/), which permits unrestricted use, distribution, and reproduction in any medium, provided you give appropriate credit to the original author(s) and the source, provide a link to the Creative Commons license, and indicate if changes were made. The Creative Commons Public Domain Dedication waiver (http://creativecommons.org/publicdomain/zero/1.0/) applies to the data made available in this article, unless otherwise stated. 


\section{Background}

Oral health is related to the overall health of individuals [1], and Petersen in the bulletin of World Health Organization (WHO) had also emphasized that, "good oral health is an integral part of general health" [2]. It is further informed that tooth decay and gum diseases are the two most common oral health problems affecting school children globally [2]. Children are the future of any nation and their health and wellbeing should be of utmost importance. These oral health problems if persisted among the children quite frequently may lead to pain, speech impairment, sleep disruption, difficulty in eating and growth disorders [3].

Epidemiologic studies report that the distribution of these oral diseases and the associated risk factors vary in different parts of the world and sometimes they also show variation within the same country or region [4]. A recent systematic review revealed that the prevalence of tooth decay is very high among Saudi Arabian school children in comparison to other developed and developing nations in the Eastern Mediterranean region [5]. A study conducted in the capital city of Saudi Arabia showed that $77.7 \%$ of school children aged $12-13$ years had been suffering from dental caries [6]. Few years later, another study in the same city demonstrated a much increased prevalence rate $(94.4 \%)$ of tooth decay [7]. Other less developed regions like Jazan, which borders Yemen have also exhibited similar data on oral health status of children and adolescents $[8,9]$.

Assessment of risk factors by Amin and Al Abad had unveiled that the increased exposure to sugared food and beverages was strongly related to the high risk of oral diseases among the school children of Riyadh [10]. Thus, there is a need to combat these oral health problems and data from diverse regions will contribute to the essential nationwide or region-based reports of these highly prevalent diseases.

The status of oral health and the associated risk factors can be assessed using multiple methods. But, most of them remain unstandardized and do not contribute to the uniformity in data representation across the nations. The World Health Organization (WHO) has provided a questionnaire for assessment of child oral health on their website, titled: "Oral health surveys: Basic methods -5 th Edition [11]. This assessment tool has a range of questions that not only evaluate the oral health status of the respondents but also identify the involvement of potential risk factors. Such tools are easy to administer even by undergraduate students, interns and dental auxiliaries in large populations. Some studies have also stated the use of these kind of tools by non-dental professionals in tertiary hospitals to gather data on the oral health status of their patients [12]. Currently, there is no Arabic version of the WHO oral health assessment tool for children. Availability of such tool will aid in collecting oral health data among child population using a unified questionnaire among the various Arabic speaking nations.

Thus, the objectives of the current study are: To validate the Arabic version of WHO child oral health assessment tool (A-OHAT); to assess the oral health status of high school children in Gizan region of Saudi Arabia; and finally, to identify the important risk factors associated with poor teeth and gum conditions of these school children. We hypothesize that the oral health status of Arab children with improper oral hygiene is poor in comparison to the children with good oral hygiene habits.

\section{Methods}

\section{Study design and study sample}

A cross-sectional study was designed and high school students residing in the Jazan region were targeted. In order to maintain the homogeneity of the study sample, only the Arab nationals studying in the public schools were included and the children from other nationalities were excluded. Adolescents were preferred as target population following the recommendation provided by the original version of the WHO oral health assessment tool [11]. This also accounted for clear interpretation of oral health status from a single set of dentitions instead of mixed dentition.

Two-staged simple random sampling technique was conducted to obtain a near-representative sample. In the first stage, random selection of four male and four female schools was done after obtaining the complete list of schools from the director's office. In the second stage, all the male and female children from the selected schools were approached. All of these students were given a consent form along with a brief description of the study proposal in order to keep the parents informed about their child's participation in this study. A minimum sample size required for this study was 400 , with an absolute precision of 0.05 , expected proportion of 0.5 and an estimated design effect of 1 [9].

\section{Reliability and validity statistics for A-OHAT}

The principal investigator had performed the forward translation into Arabic due to his fluency in both Arabic and English languages. This was followed by backward translation by a bilingual expert who was not part of the current study. Both, forward as well as backward translations were performed by taking into consideration the literal meaning of words and also the conceptual understanding of each item (question). Minor discrepancies in the Arabic version were adjusted after mutual consensus of both the translators. 
A group of fifty school children were randomly selected as respondents for the pilot study to perform the psychometric analysis of A-OHAT. The sample of 50 was suggested based on the recommendation provided by Connelly, 2008 wherein $10 \%$ of the actual sample was deemed appropriate for pilot testing [13]. Internal consistency of the translated questionnaire was explored using Chronbach's alpha and the reliability was calculated using the Intra class correlation (ICC). A paired ttest was performed to identify the differences between the readings after repeated administration of the assessment tool with a gap of 2 weeks [14].

In order to make sure that the items in the translated tool were assessing the intended isolated constructs; a convergent validity test was conducted. Spearman's correlation coefficient was performed by identifying the association between perceived oral health status of OHIP14 (Oral Health Impact Profile) and A-OHAT [15]. It was hypothesized that both of these questionnaires were revealing similar self-reported oral health status. The attached appendices demonstrate the individual items for English (Additional file 1) as well as the Arabic (Additional file 2) version of the WHO assessment tool, respectively.

\section{Data collection procedure}

Validated A-OHAT, a self-oral health assessment tool was administered to the children from the selected high schools after the signed consents from their parents were obtained. Sixth-year dental undergraduate students of Jazan University had assisted in distributing the questionnaire as part of their Community Dental Practice course (Course code - 632 PDS). Male undergraduate students approached the male high schools, while female undergraduate students approached the female high schools. On an average, the school children took twenty minutes to mark their responses.

\section{Statistical analysis}

After receiving the completed A-OHAT from the respondents, the data was recorded and analyzed using the IBM - SPSS version 24. Missing values and normality distribution were checked prior to analyses. Gender variation of perceived oral health and the associated risk factors was checked using Chi-Square test. This was done intuitively, as the male and female school children are subjected to separate schooling environments. The responses obtained from Five-point Likert scale on teeth condition and the gum condition was dichotomized into "good / poor" teeth and gum conditions, respectively. Very good / Good and Average were collapsed to 'Good condition'; whereas; Poor and Very poor were combined as 'Poor Condition', for both teeth and gum conditions, respectively. Finally, logistic regression was conducted separately to identify the potential risk factors associated with poor teeth condition and poor gum condition.

\section{Results}

\section{Psychometric properties of A-OHAT}

The mean intra class correlation (ICC) from the pilot sample of fifty school children to test the reliability on both the occasions with a gap of 2 weeks was $0.89 \pm 0.08$; and experts suggest that an ICC value of more than 0.75 gives excellent reliability [16]. Test - retest reliability using paired t-test revealed no significant difference $(P>0.05)$. The Cronbach alpha value obtained was 0.72 , which indicated a desirable internal consistency [17] (Table 1).

For identifying the convergent validity, all items were grouped under three broad constructs. Items 1, 2, 3, 16 and 17 described the demographic construct; items 4 and 5 described the oral health condition construct and finally; items $6,7,8,9,10,11,12$, and 15 described the oral habits construct. Item correlational statistics indicated that each item under their respective constructs was significantly correlated (Table 2). Responses to the global construct of oral health condition after dichotomization into Good/Poor revealed significantly higher value for the latter. Spearman correlation coefficients value of $r=1.05, P<0.05$ was obtained between perceived oral health status of OHIP-14 (Oral health impact profile) and A-OHAT.

\section{Descriptive analysis of study sample}

After the administration of the validated A-OHAT, the descriptive and regression analyses were performed. In this cross-sectional study, a total of $478(\mathrm{~N})$ high school children participated, out of which $66.5 \%$ were male and $33.5 \%$ were female. Mean age of the study sample was $16.28+1.04$ years. Nearly, $42 \%$ of school children came from urbanized locations of Jazan region and $58 \%$ came from rural locations. Most of the school children had reported that their father (43\%) and mother (36\%) had completed the university level education, respectively (Table 3).

Considering the fact that the male and female school children in Saudi Arabia are segregated into different campus environments, the authors of this study first assessed the gender variation of the dependent variable (Oral health condition). This was necessary in order to provide a clear pathway for further regression analysis,

Table 1 Reliability statistics values for Arabic-WHO assessment tool

\begin{tabular}{llc}
\hline Instrument & ICC & Cronbach's Alpha \\
\hline A-WHO & $0.89 \pm 0.08$ & 0.72 \\
\hline
\end{tabular}

ICC Intra class correlation 
Table 2 Item correlational statistics of oral health condition and the oral habits constructs

\begin{tabular}{|c|c|c|c|c|c|c|c|c|c|c|}
\hline \multicolumn{11}{|c|}{ Oral Health Condition Construct ${ }^{\mathrm{a}}$} \\
\hline & Item 4 & Item 5 & & & & & & & & \\
\hline Item 4 & 1.00 & & & & & & & & & \\
\hline Item 5 & 0.83 & 1.00 & & & & & & & & \\
\hline \multicolumn{11}{|c|}{ Oral Habits Construct ${ }^{\mathrm{a}}$} \\
\hline & & & Item 6 & Item 7 & Item 8 & Item 9 & Item 10 & Item 11 & Item 12 & Item 15 \\
\hline Item 6 & & & 1.00 & & & & & & & \\
\hline Item 7 & & & 0.89 & 1.00 & & & & & & \\
\hline Item 8 & & & 0.91 & 0.86 & 1.00 & & & & & \\
\hline Item 9 & & & 0.83 & 0.90 & 0.85 & 1.00 & & & & \\
\hline Item 10 & & & 0.83 & 0.91 & 0.90 & 0.89 & 1.00 & & & \\
\hline Item 11 & & & 0.85 & 0.89 & 0.89 & 0.83 & 0.90 & 1.00 & & \\
\hline Item 12 & & & 0.90 & 0.86 & 0.85 & 0.90 & 0.86 & 0.83 & 1.00 & \\
\hline Item 15 & & & 0.86 & 0.80 & 0.90 & 0.86 & 0.85 & 0.90 & 0.86 & 1.00 \\
\hline
\end{tabular}

atem Confirmatory factor analysis

but the results suggested no significant $(P>0.05)$ variation (Table 4). Hence, further analyses were combined for male and female school children.

Findings showed that $80.3 \%$ of school children had poor teeth condition and $36.2 \%$ of school children

Table 3 Demographic characteristics of the study sample

\begin{tabular}{|c|c|c|}
\hline Variable & Frequency & Percentage \\
\hline \multicolumn{3}{|l|}{ Gender } \\
\hline Male & 318 & $66.5 \%$ \\
\hline Female & 160 & $33.5 \%$ \\
\hline \multicolumn{3}{|l|}{ Location } \\
\hline Urban & 202 & $42.3 \%$ \\
\hline Rural & 276 & $57.7 \%$ \\
\hline \multicolumn{3}{|l|}{ Fathers Education } \\
\hline No formal schooling & 15 & $3.1 \%$ \\
\hline Less than primary school & 10 & $2.1 \%$ \\
\hline Primary school completed & 24 & $5.0 \%$ \\
\hline Secondary school completed & 37 & $7.7 \%$ \\
\hline High school completed & 94 & $19.7 \%$ \\
\hline University completed & 205 & $42.9 \%$ \\
\hline No adult male in household & 7 & $1.5 \%$ \\
\hline \multicolumn{3}{|l|}{ Mothers Education } \\
\hline No formal schooling & 47 & $9.8 \%$ \\
\hline Less than primary school & 8 & $1.7 \%$ \\
\hline Primary school completed & 43 & $9.0 \%$ \\
\hline Secondary school completed & 56 & $11.7 \%$ \\
\hline High school completed & 83 & $17.4 \%$ \\
\hline University completed & 173 & $36.2 \%$ \\
\hline No adult female in household & 3 & $0.6 \%$ \\
\hline
\end{tabular}

Mean age of the study population was $16.28 \pm 1.04$ had often experienced toothache. It was also seen that nearly $93 \%$ of high school children were not satisfied with the appearance of their teeth (Table 4). Gender variation of independent variables revealed significant difference between the diet consumption and oral hygiene habits among male and female school children (Table 5). Higher frequency of sweet food and carbohydrate consumption was seen in male school children in contrast to female school children (Table 5).

\section{Multivariate analysis of study sample}

Logistic regression was performed to identify the independent variables that contributed to the poor oral health of school children. Factors affecting teeth condition (Table 6) and gum condition (Table 7) were identified independently after adjusting for gender, location, and parent's education. It was seen that frequency of consumption of sweet and candy was significantly $(P=0.04)$ related to poor teeth condition. The school children had 1.5 times higher odds of having poor teeth condition if they had increased frequency of sweet and candy consumption (Table 6). While the assessment of factors impacting the gumcondition showed that frequency of teeth cleaning, frequency of routine dental visits, use of toothbrush and consumption of sweets and candy were significantly $(P<0.05)$ associated (Table 7). More specifically, increased frequency of sweets and candy consumption by school children had put them at nearly 3 times higher odds of having poor gum condition (Table 7). Also, school children who have the habit of using toothbrush had nearly $50 \%$ lower chance of having poor gum condition in contrast to the school children who do not use toothbrush (Table 7). 
Table 4 Gender variation of oral health problems among school children

\begin{tabular}{|c|c|c|c|c|}
\hline \multirow[t]{2}{*}{ Oral health Status } & Gender & & \multirow[t]{2}{*}{ Total } & \multirow{2}{*}{$\begin{array}{l}{ }^{*} P_{-} \\
\text {Value }\end{array}$} \\
\hline & $\begin{array}{l}\text { Boy } \\
N=318\end{array}$ & $\begin{array}{l}\text { Girl } \\
N=160\end{array}$ & & \\
\hline
\end{tabular}

Condition of teeth

$\begin{array}{lllll}\text { Excellent } & 4(1.2 \%) & 4(2.5 \%) & 8(1.7 \%) & 0.72 \\ \text { Very good } & 12(3.7 \%) & 6(3.7 \%) & 18(3.8 \%) & \\ \text { Good } & 38(11.9 \%) & 16(10.0 \%) & 54(11.3 \%) & \\ \text { Average } & 0 & 0 & 0 & \\ \text { Poor } & 257(80.8 \%) & 127(79.3 \%) & 384(80.3 \%) & \\ \text { Very poor } & 0 & 0 & 0 & \\ \text { Condition of gums } & & & & \\ \text { Excellent } & 56(17.6 \%) & 26(16.2 \%) & 82(17.2 \%) & 0.39 \\ \text { Very good } & 107(33.6 \%) & 53(33.1 \%) & 160(33.5 \%) & \\ \text { Good } & 62(19.4 \%) & 26(16.2 \%) & 88(18.4 \%) & \\ \text { Average } & 51(16.0 \%) & 33(20.6 \%) & 84(17.6 \%) & \\ \text { Poor } & 21(6.6 \%) & 7(4.3 \%) & 28(5.9 \%) \\ \text { Very poor } & 16(5.0 \%) & 14(8.7 \%) & 30(6.3 \%)\end{array}$

Toothache within past 6 months

$\begin{array}{llll}\text { Often } & 117(36.7 \%) & 56(35.0 \%) & 173(36.2 \%) \\ \text { Occasionally } & 77(24.2 \%) & 30(18.7 \%) & 107(22.4 \%) \\ \text { Rarely } & 67(21.0 \%) & 22(13.7 \%) & 89(18.6 \%) \\ \text { Never } & 38(11.9 \%) & 25(15.6 \%) & 63(13.2 \%)\end{array}$

Difficulty of chewing in past 6 months

$\begin{array}{llll}\text { No } & 18(5.6 \%) & 11(6.8 \%) & 29(6.1 \%) \\ \text { Yes } & 70(22.0 \%) & 21(13.1 \%) & 91(19.0 \%) \\ \text { Don't Remember } & 201(63.2 \%) & 100(62.5 \%) & 301(63.0 \%)\end{array}$

Difficulty to bite hard food

$\begin{array}{llll}\text { No } & 45(14.1 \%) & 19(11.8 \%) & 64(13.4 \%) \\ \text { Yes } & 37(11.6 \%) & 12(7.5 \%) & 49(10.3 \%) \\ \text { Don't Remember } & 213(66.9 \%) & 110(68.7 \%) & 323(67.6 \%)\end{array}$

Avoid smile due poor oral health

$\begin{array}{llll}\text { No } & 1(0.3 \%) & 0 & 1(0.2 \%) \\ \text { Yes } & 87(27.3 \%) & 56(35.0 \%) & 143(29.9 \%) \\ \text { Don't Remember } & 210(66.0 \%) & 102(63.7 \%) & 312(65.3 \%)\end{array}$

Friends make fun of my teeth

$\begin{array}{lllll}\text { No } & 32(10.1 \%) & 13(8.1 \%) & 45(9.4 \%) & 0.10 \\ \text { Yes } & 154(48.4 \%) & 63(39.3 \%) & 217(45.4 \%) & \\ \text { Don't Remember } & 120(37.7 \%) & 75(46.8 \%) & 195(40.8 \%) & \end{array}$

Dissatisfied with my teeth appearance

\begin{tabular}{lllll} 
No & $13(4.1 \%)$ & $3(1.8 \%)$ & $16(3.3 \%)$ & 0.13 \\
Yes & $291(91.5 \%)$ & $157(98.1 \%)$ & $448(93.7 \%)$ & \\
\hline
\end{tabular}

${ }^{*} P$-value determined using chi-square analysis

\section{Discussion}

The current study is first to provide a WHO oral health self-assessment tool (A-OHAT) that can be administered to a wide range of Arabic speaking child populations, especially in the Eastern Mediterranean region (Additional file 2). Findings of psychometric analyses from the current study are in accordance with a similar WHO oral health assessment tool constructed for adults and tested for its reliability and validity [18]. The current study is also the first to describe the oral health status of high school children (Mean age $=16$ years) residing in Jazan region of Saudi Arabia utilizing a self-assessment tool. The high prevalence of school children with poor teeth condition observed in the current study was similar to the reports from other developing [19] as well as developed nations [20] among children of same age range. However, there are no results from similar age group in Jazan region for comparison, but studies conducted in much younger children have also shown high prevalence of clinically examined tooth decay $[8$, 9, 21].

Further, results from the current study had revealed that both male and female children have quite often experienced toothache, and this may subsequently affect their daily activities [22] and also increase the possibility of school absenteeism [23]. These types of associations through the application of Oral health related Quality of Life assessment tools like Child-Oral Impact on Daily Performances (Child-OIDP) have to be further explored in the Arab population.

The assessment of potential risk factors indicated that the increased frequency of sweet food consumption among the adolescents was significantly associated with their poor teeth condition and this finding was in accordance with an earlier study performed among children of different age groups in this region [9]. The gum condition of the study population was also reported to be poor by most of the school children. Potential risk factors related with poor gum condition were identified as: 'fewer visits to oral health care providers', decreased 'frequency of mouth cleaning' and 'not using the toothbrush'. Studies conducted elsewhere have also put forth that poor oral hygiene maintenance is directly related with poor gum condition [24-26]. It is to be noted that the dental care in Saudi Arabia is free and managed by the Ministry of Health $(\mathrm{MoH})$ with nearly 314 tertiary hospital and 1756 primary health centers. Each governorate has an access to at least one primary dental center which acts as a referral route to more equipped dental hospitals [10]. Ironically, the utilization rates of oral health care among the children and adolescents which could act as a potential 
Table 5 Description of independent variables among male and female school children

\begin{tabular}{|c|c|c|c|c|}
\hline \multirow{2}{*}{$\begin{array}{l}\text { Diet } \\
\text { Fruits }\end{array}$} & \multicolumn{2}{|l|}{ Gender } & \multirow[t]{2}{*}{ Total } & \multirow[t]{2}{*}{$P$-Value } \\
\hline & $\begin{array}{l}\text { Male } \\
N=318\end{array}$ & $\begin{array}{l}\text { Female } \\
N=160\end{array}$ & & \\
\hline Never & $19(6 \%)$ & $24(15 \%)$ & $43(9.0 \%)$ & $<0.001^{*}$ \\
\hline Several times a month & $61(19.2 \%)$ & $46(28.7 \%)$ & $107(22.4 \%)$ & \\
\hline Once a week & $58(18.2 \%)$ & $26(16.2 \%)$ & $84(17.6 \%)$ & \\
\hline Several times a week & $94(29.5 \%)$ & 37 (23.1\%) & $131(27.4 \%)$ & \\
\hline Everyday & $55(17.3 \%)$ & $12(7.5 \%)$ & 67 (14.0\%) & \\
\hline Several times a day & 29 (9.1\%) & $14(10.6 \%)$ & $43(9.0 \%)$ & \\
\hline \multicolumn{5}{|l|}{ Lemonade } \\
\hline Never & $17(5.3 \%)$ & $11(6.9 \%)$ & $28(5.9 \%)$ & \multirow[t]{6}{*}{0.50} \\
\hline Several times a month & $20(6.3 \%)$ & 15 (9.4\%) & $35(7.3 \%)$ & \\
\hline Once a week & $20(6.3 \%)$ & $13(8.1 \%)$ & $33(6.9 \%)$ & \\
\hline Several times a week & $57(17.9 \%)$ & $31(19.4 \%)$ & $88(18.4 \%)$ & \\
\hline Everyday & $123(38.7 \%)$ & $50(31.2 \%)$ & $173(36.9 \%)$ & \\
\hline Several times a day & 77 (24.2\%) & 35 (21.9\%) & $112(23.9 \%)$ & \\
\hline \multicolumn{5}{|l|}{ Jam and Honey } \\
\hline Never & $85(26.7 \%)$ & 70 (43.7\%) & $155(32.4 \%)$ & \multirow[t]{6}{*}{$<0.001^{*}$} \\
\hline Several times a month & $69(21.7 \%)$ & $35(21.8 \%)$ & $104(21.8 \%)$ & \\
\hline Once a week & $39(12.3 \%)$ & $21(13.1 \%)$ & $60(12.6 \%)$ & \\
\hline Several times a week & $66(20.7 \%)$ & $20(12.5 \%)$ & $86(18.0 \%)$ & \\
\hline Everyday & $34(10.7 \%)$ & $3(1.9 \%)$ & $37(7.7 \%)$ & \\
\hline Several times a day & $14(4.4 \%)$ & $6(3.7 \%)$ & $20(4.2 \%)$ & \\
\hline \multicolumn{5}{|l|}{ Sweet and Candy } \\
\hline Never & $27(8.5 \%)$ & $12(7.5 \%)$ & $39(8.2 \%)$ & \multirow[t]{6}{*}{0.63} \\
\hline Several times a month & $22(6.9 \%)$ & 15 (9.4\%) & $37(7.7 \%)$ & \\
\hline Once a week & $30(9.4 \%)$ & $12(7.5 \%)$ & $42(8.8 \%)$ & \\
\hline Several times a week & $84(26.4 \%)$ & $36(22.5 \%)$ & $120(25.1 \%)$ & \\
\hline Everyday & $96(30.2 \%)$ & $48(3 \%)$ & $144(30.1 \%)$ & \\
\hline Several times a day & $54(17 \%)$ & 35 (21.9\%) & $89(18.6 \%)$ & \\
\hline \multicolumn{5}{|l|}{ Milk with Sugar } \\
\hline Never & $24(7.5 \%)$ & $8(5 \%)$ & $32(6.7 \%)$ & \multirow[t]{6}{*}{$<0.001^{*}$} \\
\hline Several times a month & $25(7.9 \%)$ & $10(6.2 \%)$ & $35(7.3 \%)$ & \\
\hline Once a week & $44(13.8 \%)$ & $13(8.1 \%)$ & $57(11.9 \%)$ & \\
\hline Several times a week & $94(29.5 \%)$ & $26(16.2 \%)$ & $120(25.1 \%)$ & \\
\hline Everyday & 78 (24.5\%) & $59(36.9 \%)$ & $137(28.7 \%)$ & \\
\hline Several times a day & $45(14.5 \%)$ & $42(26.2 \%)$ & $87(18.2 \%)$ & \\
\hline \multicolumn{5}{|l|}{ Tea with Sugar } \\
\hline Never & $69(21.7 \%)$ & $41(25.6 \%)$ & $110(23 \%)$ & \multirow[t]{6}{*}{$0.002^{*}$} \\
\hline Several times a month & $46(14.5 \%)$ & $36(22.5 \%)$ & $82(17.2 \%)$ & \\
\hline Once a week & $42(13.2 \%)$ & $20(12.5 \%)$ & $62(13.0 \%)$ & \\
\hline Several times a week & 73 (23\%) & $27(16.9 \%)$ & $100(20.9 \%)$ & \\
\hline Everyday & $61(19.2 \%)$ & $13(8.1 \%)$ & $74(15.5 \%)$ & \\
\hline Several times a day & $22(7 \%)$ & $20(12.5 \%)$ & $42(8.8 \%)$ & \\
\hline
\end{tabular}

Coffee with Sugar 
Table 5 Description of independent variables among male and female school children (Continued)

\begin{tabular}{llll}
\hline Diet & Gender & & Total \\
\hline Never & $40(12.6 \%)$ & $30(18.7 \%)$ & $70(14.6 \%)$ \\
Several times a month & $31(9.7 \%)$ & $23(14.3 \%)$ & $54(11.3 \%)$ \\
Once a week & $37(11.6 \%)$ & $26(16.2 \%)$ & $63(13.2 \%)$ \\
Several times a week & $85(26.7 \%)$ & $33(20.6 \%)$ & $118(24.7 \%)$ \\
Everyday & $76(23.9 \%)$ & $26(16.2 \%)$ & $102(21.3 \%)$ \\
Several times a day & $42(13.2 \%)$ & $20(12.5 \%)$ & $62(13.0 \%)$ \\
\hline
\end{tabular}

*Significant $P$-value determined using chi-square analysis

Table 6 Risk factors affecting teeth condition of school children

\begin{tabular}{|c|c|c|c|c|c|c|}
\hline \multirow[t]{2}{*}{ Risk factors } & \multicolumn{2}{|c|}{ Teeth Condition } & \multirow{2}{*}{$\begin{array}{l}P \text { - } \\
\text { Value }\end{array}$} & \multirow{2}{*}{$\begin{array}{l}\text { Adjusted } \\
{ }^{a} \text { O.R }\end{array}$} & \multicolumn{2}{|c|}{ Confidence Interval } \\
\hline & Good & Poor & & & Minimum & Maximum \\
\hline \multicolumn{7}{|l|}{ Teeth Cleaning Frequency } \\
\hline Once & 3 & 18 & 0.26 & 0.91 & 0.77 & 1.07 \\
\hline Twice & 7 & 32 & & & & \\
\hline Three times & 7 & 17 & & & & \\
\hline Four times & 9 & 37 & & & & \\
\hline More than four times & 27 & 129 & & & & \\
\hline \multicolumn{7}{|l|}{ Routine Dental Visit } \\
\hline Once & 64 & 16 & 0.12 & 0.84 & 0.67 & 1.04 \\
\hline Twice & 87 & 30 & & & & \\
\hline Three Times & 142 & 19 & & & & \\
\hline Four Times & 69 & 7 & & & & \\
\hline More than 4 times & 33 & 8 & & & & \\
\hline \multicolumn{7}{|l|}{ Sweets and Candy } \\
\hline Never & 33 & 6 & $0.04^{*}$ & 1.50 & 1.00 & 1.44 \\
\hline Several times a month & 33 & 4 & & & & \\
\hline Once a week & 35 & 7 & & & & \\
\hline Several times a week & 8 & 112 & & & & \\
\hline Everyday & 35 & 109 & & & & \\
\hline Several times a day & 20 & 69 & & & & \\
\hline \multicolumn{7}{|l|}{ Fluoridated Toothpaste } \\
\hline Yes & 2 & 12 & 0.98 & 0.98 & 0.20 & 4.65 \\
\hline No & 78 & 386 & & & & \\
\hline \multicolumn{7}{|l|}{ Mothers Education } \\
\hline No Schooling & 10 & 37 & 0.34 & 0.94 & 0.82 & 1.06 \\
\hline Less than primary school & 3 & 5 & & & & \\
\hline Primary School Completed & 5 & 38 & & & & \\
\hline Secondary School Completed & 15 & 41 & & & & \\
\hline High School Completed & 23 & 60 & & & & \\
\hline University Completed & 14 & 159 & & & & \\
\hline
\end{tabular}

*Significant $P$-value determined using chi-square analysis

$O . R$ Odds ratio determined using ENTER method

${ }^{a} O$. $R$ Adjusted for gender, location and parent's education 
Table 7 Risk factors affecting gum condition of school children

\begin{tabular}{|c|c|c|c|c|c|c|}
\hline \multirow[t]{2}{*}{ Risk factorsa } & \multicolumn{2}{|c|}{ Gum Condition } & \multirow[t]{2}{*}{$P$-Value } & \multirow{2}{*}{$\begin{array}{l}\text { Adjusted } \\
\text { a O.R }\end{array}$} & \multicolumn{2}{|c|}{ Confidence Interval } \\
\hline & Good & Poor & & & Minimum & Maximum \\
\hline Teeth Cleaning Frequency & $(N=190)$ & $(N=59)$ & & & & \\
\hline Once & $10(52 \%)$ & $11(18.6 \%)$ & $0.02^{*}$ & 1.18 & 1.02 & 1.36 \\
\hline Twice & $25(13.1 \%)$ & $14(23.7 \%)$ & & & & \\
\hline Three times & $15(7.8 \%)$ & $9(15.2 \%)$ & & & & \\
\hline Four times & $32(16.8 \%)$ & $14(23.7 \%)$ & & & & \\
\hline More than four times & $108(56.8 \%)$ & $11(18.6 \%)$ & & & & \\
\hline Routine Dental Visit & $(N=330)$ & $(N=145)$ & & & & \\
\hline Once & $47(14.2 \%)$ & $33(22.7 \%)$ & $<0.001^{*}$ & 1.39 & 1.15 & 1.68 \\
\hline Twice & $61(18.4 \%)$ & $56(38.6 \%)$ & & & & \\
\hline Three Times & $130(39.3 \%)$ & $31(21.3 \%)$ & & & & \\
\hline Four Times & $62(18.7 \%)$ & $14(9.6 \%)$ & & & & \\
\hline More than 4 times & $30(9.0 \%)$ & $11(75 \%)$ & & & & \\
\hline Sweets and Candy & $(N=160)$ & $(N=311)$ & & & & \\
\hline Never & $27(16.8 \%)$ & $12(3.8 \%)$ & $0.05^{*}$ & 2.86 & 0.74 & 3.00 \\
\hline Several times a month & $11(6.8 \%)$ & $26(8.3 \%)$ & & & & \\
\hline Once a week & $8(5 \%)$ & $34(10.9 \%)$ & & & & \\
\hline Several times a week & 29 & 91 & & & & \\
\hline Everyday & $51(31.8 \%)$ & 93 (29.9\%) & & & & \\
\hline Several times a day & $34(21.2 \%)$ & $55(17.6 \%)$ & & & & \\
\hline Toothbrush & $(N=330)$ & $(N=148)$ & & & & \\
\hline Yes & 300 (90.9\%) & $124(83.7 \%)$ & $0.04^{*}$ & 0.49 & 0.25 & 0.96 \\
\hline No & $30(9 \%)$ & $24(16.2 \%)$ & & & & \\
\hline Smokeless Tobacco & $(N=139)$ & $(N=317)$ & & & & \\
\hline Never & 135 (97.1\%) & 298 (94\%) & 0.15 & 1.31 & 0.90 & 1.92 \\
\hline Seldom & $2(1.4 \%)$ & $8(2.5 \%)$ & & & & \\
\hline Several Times In Month & 0 & $1(0.3 \%)$ & & & & \\
\hline Several Times A Week & $1(0.7 \%)$ & $2(0.6 \%)$ & & & & \\
\hline Every Day & $1(0.7 \%)$ & $8(2.5 \%)$ & & & & \\
\hline Smoked Tobacco & $(N=308)$ & $(N=137)$ & & & & \\
\hline Never & 277 (89.9\%) & $124(90.5 \%)$ & 0.95 & 1.00 & 0.83 & 1.21 \\
\hline Seldom & $16(5.1 \%)$ & $4(2.9 \%)$ & & & & \\
\hline Several Times In Month & $8(2.5 \%)$ & $3(2.1 \%)$ & & & & \\
\hline Several Times A Week & $3(0.9 \%)$ & $2(1.4 \%)$ & & & & \\
\hline Every Day & $4(1.2 \%)$ & $4(2.9 \%)$ & & & & \\
\hline
\end{tabular}

*Significant $P$-value determined using chi-square analysis

$O . R$ Odds ratio determined using ENTER method

${ }^{a} O$. $R$ Adjusted for gender, location and parent's education

risk factor for oral health status of the population has not been studied and reported [27].

In addition to the above mentioned factors, some of the previous reports have also mentioned that 'mothers education' and 'family income' are closely associated with gingival inflammation [25]. On the contrary, these factors have not shown any influence on poor gum condition in the current sample. This could be attributed to the homogeneity maintained among the study population. On searching the literature, it is observed that there are very few published studies from the middle-east region which report on the gum condition of school children and its associated risk factors. The Global data provided by WHO have stated that more than $80 \%$ of the child population across the world suffers from some or the other form of gum problems [11]. This suggests 
that there is a need of further studies to explore the grade of gum inflammation and also the associated risk factors in this region.

Robust psychometric analysis and random selection of the participants is the strength of the study and it demonstrates the internal and external validity of the study. During the initial forward and backward translation, the Arabic-WHO child oral health assessment tool reflected the quality and originality of its English version [11]. The tested A-OHAT is extremely easy to administer and the authors recommend that this tool could be utilized by health auxiliaries, graduating students and in many cases by school authorities (Educators) to identify oral health status of their school children. Thus, contributing to the early detection of oral health problems in children so that appropriate and timely measures are initiated. Further, we also suggest that such assessment tools can be applied in multi-center studies were data from different regional populations could be gathered in a much easier fashion maintaining the generalizability. The data gathered will thus contribute to global findings through a standardized assessment tool.

However, the current study has its limitations that are important to be considered during the interpretation of the findings. The administrative tool determines the oral health status subjectively and clinical examination of oral cavity will provide more accurate and comprehensive findings. Also, the design is cross-sectional and hence does not demonstrate the temporality between the oral health conditions and the potential risk factors.

\section{Conclusions}

To conclude, the current study provides a reliable and valid tool to assess the oral health status of children in Arabic speaking nations. The teeth and gum condition of the Arab adolescents in this study was generally poor; and improper oral hygiene habits and diet were identified as the plausible risk factors.

\section{Supplementary information}

Supplementary information accompanies this paper at https://doi.org/10. 1186/s12903-020-1018-8

Additional file 1. WHO-OHAT Demonstrates the individual items for the English version of the Oral Health Assessment Tool provided by the World Health Organization.

Additional file 2. A-OHAT Demonstrates the individual items for the current validated Arabic version of the Oral Health Assessment Tool.

\section{Abbreviations}

A-OHAT: Arabic-Oral health assessment tool; ICC: Intra class correlation; OHIP: Oral health impact profile; OIDP: Oral impact on daily performance; WHO: World Health Organization

\section{Acknowledgements}

The authors would like to acknowledge the school children for their cooperation and school authorities for their administrative help. The authors also extend their sincere regards to the final year dental undergraduate students of Jazan University for their assistance in data collection.

\section{Author's declaration}

Authors declare that the A-OHAT document has been provided as a supplementary file (Additional file 2) with the current submission which may be used by the researchers and other health care providers for future oral health investigations.

\section{Authors' contributions}

The $A B$ had generated the idea of the study. $A B$ and MFAQ designed the methodology of the study. MFAQ performed the analysis and $A B$ contributed sufficiently. Finally, $A B$ and MFAQ contributed equally in manuscript writing. Both authors have read and approve the manuscript.

\section{Funding}

The current study was self-funded and no fund from any external sources was received.

\section{Availability of data and materials}

The data used to support the findings of this study are available from the corresponding author upon request.

\section{Ethics approval and consent to participate}

Permission to conduct the study was granted by the Research Unit at the School of Dentistry, Jazan University (Dated: 15th of March 2018) after the initial presentation of the study proposal. This was followed by an approval from the regional Director of Education to visit the government schools in Gizan. Finally, informed verbal consent from the school children, and a written-signed consent from their parents were obtained prior to the collection of data.

\section{Consent for publication}

Not Applicable.

\section{Competing interests}

The authors for the current study declare that there are no competing interests with regards to funding, methodology and findings of the current study.

Received: 1 November 2018 Accepted: 22 January 2020

Published online: 28 January 2020

\section{References}

1. Shieham A. Oral health, general health and quality of life. Bull World Health Organ. 2005;83(9):644.

2. Petersen P, Bourgeois D, Ogawal H, Estupinan-Dayll S, Ndiayelll C. The global burden of oral diseases and risks to oral health. Bull World Health Organ. 2005;83(9):661-9.

3. Frencken JE, Sharma P, Stenhouse L, Green D, Laverty D, Dietrich T. Global epidemiology of dental caries and severe periodontitis - a comprehensive review. J Clin Periodontol. 2017:44(S18):S94-S105.

4. GBD. Disease and Injury Incidence and Prevalence Collaborators. Global, regional, and national incidence, prevalence, and years lived with disability for 328 diseases and injuries for 195 countries, 1990-2016: a systematic analysis for the Global Burden of Disease Study. Lancet. 2017;390(10100): 1211-59.

5. AI AD. A systematic review of population-based dental caries studies among children in Saudi Arabia. Saudi Dent J. 2013;25(3):11.

6. Akpata ES, Al-Shammery AR, Saeed HI. Dental caries, sugar consumption and restorative dental care in 12-13-year-old children in Riyadh, Saudi Arabia. Community Dent Oral Epidemiol. 1992;20(6):343.

7. Wazzan K. Dental caries prevalence in 6-7 year old school children in Riyadh region: a comparative study with the 1987 Oral health survey of Saudi Arabia phase I. Saudi Dent J. 2004;16:54-60.

8. Alzailai A, Quadri M, Nayeem M, Inamdar A, Tadakamadla S. Caries status of school children in Jazan city, KSA and its relation with dental literacy of their parents. J Oral Health Res. 2014;5(1):5.

9. Quadri FA, Hendriyani H, Pramono A, Jafer M. Knowledge, attitudes and practices of sweet food and beverage consumption and its association with 
dental caries among schoolchildren in Jazan, Saudi Arabia. East Mediterr Health J. 2015;21(6):403-11.

10. Amin TA-A, BM. Oral hygiene practices, dental knowledge, dietary habits and their relation to caries among male primary school children in Al Hassa, Saudi Arabia. Int J Dent Hyg. 2008;6(4):361-70.

11. WHO. Oral health surveys: basic methods - 5th edition. Annex 8: WHO - Oral health questionnaire for children; 2018. https://www.who.int/oral_health/ publications/9789241548649/en/.

12. Blevins J. Status of oral health care in hospitalized children. Am J Matern Child Nurs. 2013;38(2):115-9.

13. Connelly L. Pilot studies. Medsurg Nurs. 2008;17(6):411-2.

14. Osman SM, Khalifa N, Alhajj MN. Validation and comparison of the Arabic versions of GOHAl and OHIP-14 in patients with and without denture experience. BMC Oral Health. 2018;18(1):157.

15. Farsi NJ, El-Housseiny AA, Farsi DJ, Farsi NM. Validation of the Arabic version of the early childhood Oral health impact scale (ECOHIS). BMC Oral Health. 2017;17(1):60

16. Shrout PF, JL. Intraclass correlations: uses in assessing rater reliability. Psychol Bull. 1979;86:420-8.

17. Bland JA, DG. Statistics notes: Cronbach's alpha. BMJ. 1997;314:572.

18. Khoshnevisan MH, Albujeer AN, Attaran N, Almahafdha A, Taher A. WHO's oral health assessment questionnaire for adult: psychometric properties of the Arabic version. Journal of Contemp Med Sci. 2016;2(7):116-8.

19. BAea AGOSTINI. Self-perceived Oral health influences tooth brushing in preschool children. Braz Dent J. 2014;25(3):248-52.

20. Ostberg AL, Lindblad U, Halling A. Self-perceived oral health in adolescents associated with family characteristics and parental employment status. Community Dent Health. 2003;20(3):159-64.

21. Quadri MFA, Shubayr MA, Hattan AH, Wafi SA, Jafer AH. Oral hygiene practices among Saudi Arabian children and its relation to their dental caries status. Int J Dent. 2018;2018:6.

22. Yusof ZY, Jaafar N. A Malay version of the child Oral impacts on daily performances (child-OIDP) index: assessing validity and reliability. Health Qual Life Outcomes. 2012;10(1):63.

23. Shaikh S, Siddiqui AA, Aljanakh M. School Absenteeism due to Toothache among Secondary School Students Aged 16\&\#x2013;18 Years in the Ha\&\#×2019;il Region of Saudi Arabia. Pain Res Treat. 2016;2016:4.

24. Albandar JM. Epidemiology and risk factors of periodontal diseases. Dent Clin. 2005:49(3):517-32.

25. de Castilho LS, Abreu MH, de Souza DH, Souza ME, Resende VL. Factors associated with gingivitis in children with developmental disabilities. Braz Res Pediatr Dent Integr Clin. 2016;16(1):441-8.

26. Al-Ghutaimel H, Riba H, Al-Kahtani S, Al-Duhaimi S. Common periodontal diseases of children and adolescents. Int J Dent. 2014;10(11):7.

27. Quadri FA, Jafari FA, Albeshri AT, Zailai AM. Factors influencing Patients' utilization of dental health Services in Jazan, Kingdom of Saudi Arabia. Int J Clin Pediatr Dent. 2018;11(1):29-33.

\section{Publisher's Note}

Springer Nature remains neutral with regard to jurisdictional claims in published maps and institutional affiliations.

Ready to submit your research? Choose BMC and benefit from:

- fast, convenient online submission

- thorough peer review by experienced researchers in your field

- rapid publication on acceptance

- support for research data, including large and complex data types

- gold Open Access which fosters wider collaboration and increased citations

- maximum visibility for your research: over $100 \mathrm{M}$ website views per year

At $\mathrm{BMC}$, research is always in progress.

Learn more biomedcentral.com/submissions 